\title{
Health Care for Immigrants - Implications of Obama's Executive Action
}

\section{Citation}

Sommers, Benjamin D., and Wendy E. Parmet. 2015. "Health Care for Immigrants Implications of Obama's Executive Action." N Engl J Med 372 (13) (March 26): 1187-1189. doi:10.1056/nejmp1414949.

\section{Published Version}

doi:10.1056/NEJMp1414949

\section{Permanent link}

http://nrs.harvard.edu/urn-3:HUL.InstRepos:14302700

\section{Terms of Use}

This article was downloaded from Harvard University's DASH repository, and is made available under the terms and conditions applicable to Other Posted Material, as set forth at http:// nrs.harvard.edu/urn-3:HUL.InstRepos:dash.current.terms-of-use\#LAA

\section{Share Your Story}

The Harvard community has made this article openly available.

Please share how this access benefits you. Submit a story.

\section{Accessibility}




\title{
Health Care for Immigrants - Implications of Obama's Executive Action
}

\author{
Benjamin D. Sommers, M.D., Ph.D., and Wendy E. Parmet, J.D.
}

O November 20, 2014, President Barack Obama announced his intention to grant millions of undocumented immigrants a reprieve from the threat of deportation, along with the possibility of legal employment in the United States. The announcement came shortly after midterm elections that saw Republicans take control of the Senate and bolster their majority in the House of Representatives, and it followed more than a year of congressional gridlock over the comprehensive immigrationreform bill passed by the Senate. The subsequent decision by a federal district judge in Texas to put President Obama's plan on hold has cast into doubt a policy that - if ultimately upheld could have substantial effects on the health care system.

The cornerstone of the President's policy is a plan to allow up to 5 million undocumented immigrants ("covered immigrants") to live and work in the United States. Modeled on the 2012 Deferred Action for Childhood Arrivals (DACA) program, which applied to young adults who arrived in the United States as children, the new policy will allow many more adults who have been here since 2010 to receive deferred-action status. The population affected by the policy is one that currently experiences major disparities in health care coverage and access. Immigrants are far more likely than nativeborn residents to be uninsured: among adults, an estimated 40\% of legal permanent residents and $71 \%$ of undocumented immigrants are uninsured, as compared with $15 \%$ of U.S.-born citizens. $^{1}$ Not surprisingly, health care utilization is far lower among immigrants than among citizens. $^{2}$

Although the President's policy does not explicitly address health care, it will most likely increase access to insurance among covered immigrants and members of their family through a variety of direct and indirect means (see table).

Many of the coverage gains are likely to occur in the private sector. The President's plan to issue legal work permits for undocumented immigrants could open the doors for many individuals and families to gain employer-sponsored health insurance for the first time. An estimated $29 \%$ of undocumented immigrants already have private insurance, and many more immigrants are likely to find jobs that offer benefits once they are legally authorized to work - though these gains may be tempered somewhat by the fact that immigrants disproportionately work in jobs that are less likely to include health benefits. ${ }^{1}$

Moreover, under the employer mandate included in the Affordable Care Act (ACA), employers with 100 or more full-time employees have to pay a penalty if any of their full-time workers receive tax credits to purchase in- surance through an exchange. To the extent that the mandate encourages employers to cover all employees, covered immigrants - who may find it easier to gain employment in areas from which they have previously been barred - will benefit. On the other hand, because covered immigrants will remain ineligible for premium tax credits, employers will not have to worry about paying a penalty for their receiving premium subsidies. Hence, although the ACA prohibits employers from discriminating against workers who purchase insurance through the exchanges, it may create a perverse incentive for employers who don't offer affordable coverage to hire covered immigrants.

In addition to increasing covered immigrants' access to employer-provided insurance, the President's plan may enable covered immigrants to take better advantage of the many provisions in the ACA that apply to private plans purchased directly from insurers, such as the elimination of exclusions for preexisting conditions.

Notably, however, the Obama administration has indicated that immigrants covered under the new policy will continue to be excluded from the ACA's exchanges and tax credits. Similarly, immigrants targeted by the executive action will for the most part remain ineligible for federally funded Medicaid, though some states do provide publicly 
Potential Effects of Deferred Action for Undocumented Immigrants on Health Insurance Coverage.*

\begin{tabular}{|c|c|c|}
\hline Type of Health Insurance & Population Affected & Comments \\
\hline $\begin{array}{l}\text { Employer-sponsored } \\
\text { health insurance }\end{array}$ & $\begin{array}{l}\text { Undocumented immigrants receiving deferred- } \\
\text { action status and their dependents }\end{array}$ & $\begin{array}{l}\text { Work permits may expand employment opportunities and the } \\
\text { likelihood of being offered health benefits. }\end{array}$ \\
\hline $\begin{array}{l}\text { Individual private insur- } \\
\text { ance not sold through } \\
\text { an exchange }\end{array}$ & $\begin{array}{l}\text { Undocumented immigrants receiving deferred- } \\
\text { action status and their dependents }\end{array}$ & $\begin{array}{l}\text { Work permits may increase income and willingness to apply for } \\
\text { coverage. ACA regulations (e.g., no exclusions for preexisting } \\
\text { conditions, community-rated premiums) apply to these plans }\end{array}$ \\
\hline Medicaid & $\begin{array}{l}\text { Legal residents and citizens with undocumented } \\
\text { family members }\end{array}$ & $\begin{array}{l}\text { With deportation risk removed, eligible family members may } \\
\text { be more likely to sign up for public coverage. Undocumented } \\
\text { immigrants will generally still not be eligible for federal } \\
\text { Medicaid funds. }\end{array}$ \\
\hline ACA exchange plans & $\begin{array}{l}\text { Legal residents and citizens with undocumented } \\
\text { family members }\end{array}$ & $\begin{array}{l}\text { With deportation risk removed, eligible family members may be } \\
\text { more likely to apply for coverage and tax credits. Undocu- } \\
\text { mented immigrants will still not be eligible for exchange } \\
\text { plans or subsidies. }\end{array}$ \\
\hline Medicare & $\begin{array}{l}\text { Undocumented immigrants receiving deferred- } \\
\text { action status }\end{array}$ & $\begin{array}{l}\text { The White House has suggested it may grant Medicare } \\
\text { eligibility to those meeting payroll-tax-contribution } \\
\text { requirements and other eligibility criteria (related to age, } \\
\text { health status, or disability). }\end{array}$ \\
\hline
\end{tabular}

* ACA denotes Affordable Care Act.

funded health insurance for some classes of undocumented immigrants. To the extent that work permits lead to an increase in taxes paid by undocumented immigrants, ongoing exclusion of these immigrants from the programs supported by such taxes would be increasingly inequitable.

In contrast, there have been reports that the administration may deem covered immigrants "lawfully present" for the purposes of Medicare - which would mean that they could receive coverage if they met the other eligibility criteria, which generally include having a family or personal history of contributing payroll taxes, in addition to being at least 65 years old or having a disability or end-stage renal disease. $^{3}$ Although most of the newly covered immigrants are too young to qualify for Medicare now, this policy would affect those who develop disabilities after working the requisite period and for those who age into Medicare in the future.

Although the President's deferred-action policy is likely to have a positive effect on insurance coverage of undocumented immigrants, it may, counterintuitively, do more to increase access to insurance for legal immigrants and even citizens than it does for those directly affected by the planned executive order. Previous research has shown that in mixedstatus families (those in which some members are undocumented and others are legal immigrants or citizens), the perceived threat of deportation is associated with lower participation rates in programs such as Medicaid and the Children's Health Insurance Program. ${ }^{4,5}$ Eliminating the threat of deportation may induce undocumented parents to sign their U.S.-born children up for coverage and legal immigrants with undocumented relatives to enroll in Medicaid or subsidized exchange plans. The resulting changes are likely to be greatest in Hispanic and Asian communities, including children, and they may narrow some of the country's racial and ethnic disparities in coverage.

Similarly, the reduced threat of deportation may mitigate immigrants' mistrust as they decide whether to pursue needed medical care, regardless of their insurance status. Ironically, any resulting increase in utilization may exacerbate the financial strain placed on safety-net providers that disproportionately care for immigrants, since many immigrants will remain uninsured if they are ineligible for Medicaid or premium tax credits. Policymakers will therefore need to continue funding streams to support providers who care for uninsured immigrants.

Thus, there is reason to expect that President Obama's new immigration policy will increase insurance coverage and health care access among undocumented immigrants and their relatives. But it remains unclear exactly how these changes will play out, given that any executive policy especially one as contentious as this one - is temporary by nature. The extent to which the President's policy will encourage uninsured people in immigrant communities (undocumented or 
otherwise) to emerge from the shadows and obtain coverage is largely contingent on the perceived political and legal climate. Earlier this year, Republican Congressional leaders attempted, ultimately unsuccessfully, to tie funding for the Department of Homeland Security to the dismantlement of the program. Meanwhile, the decision by a federal judge to temporarily halt the policy in response to a lawsuit filed by 26 states raises the possibility that the program's fate will end up being decided by the Supreme Court. These uncertainties may leave many immigrants reluctant to come forward and seek coverage. And any gains may be ephemeral if the policy is ultimately reversed by the courts, legislative action, or a future President.
Overall, the President's policy — if implemented - is likely to increase insurance coverage in immigrant communities. Nevertheless, most undocumented immigrants in the United States will remain significantly limited in their ability to obtain health insurance and to access needed health care. ${ }^{2}$ Beyond the surrounding legal and political controversies, this executive action is no substitute for a comprehensive immigration-reform law that addresses the health needs of immigrants. Given the gridlock in Washington, D.C., however, such a law seems an improbable aspiration.

Disclosure forms provided by the authors are available with the full text of this article at NEJM.org.

From the Department of Health Policy and Management, Harvard School of Public Health (B.D.S.), and Northeastern University School of Law (W.E.P.) - both in Boston.
1. Capps R, Bachmeier JD, Fix M, Van HookJ. A demographic, socioeconomic, and health coverage profile of unauthorized immigrants in the United States. Washington, DC: Migration Policy Institute, May 2013.

2. Bustamante AV, Chen J. Health expenditure dynamics and years of U.S. residence: analyzing spending disparities among Latinos by citizenship/nativity status. Health Serv Res 2012:47:794-818.

3. Tumulty K. Illegal immigrants could receive Social Security, Medicare under Obama action. Washington Post. November 25, 2014 (http://www.washingtonpost.com/politics/ illegal-immigrants-could-receive-social-security -medicare-under-obama-action/2014/11/25/ 57lcaefe-74d4-1le4-bdlb-03009bd3e984 story.html).

4. Sommers BD, Tomasi MR, Swartz K, Epstein AM. Reasons for the wide variation in Medicaid participation rates among states hold lessons for coverage expansion in 2014. Health Aff (Millwood) 2012;31:909-19. [Errata, Health Aff (Millwood) 2012;31:1650, 2831.]

5. Watson T. Inside the refrigerator: immigration enforcement and chilling effects in Medicaid participation. Cambridge, MA: National Bureau of Economic Research, August 2010.

DOI: 10.1056/NEJMp1414949

Copyright @) 2015 Massachusetts Medical Society.

\title{
Forced Vital Capacity in Idiopathic Pulmonary Fibrosis FDA Review of Pirfenidone and Nintedanib
}

\author{
Banu A. Karimi-Shah, M.D., and Badrul A. Chowdhury, M.D., Ph.D.
}

Tiopathic pulmonary fibrosis (IPF) is a devastating disease of unknown cause, and for years the only effective treatment available was lung transplantation. In October 2014, two drugs became available in the United States for patients with IPF when the Food and Drug Administration (FDA) approved pirfenidone (Esbriet, InterMune) and nintedanib (Ofev, Boehringer Ingelheim). ${ }^{1}$ Both drugs posed a similar regulatory challenge, in that the primary efficacy variable studied in both cases was the change in forced vital capacity (FVC). FVC, a measure of lung function, had not been established as a surrogate for clinically meaningful benefit in IPF.

Pirfenidone, a pyridone, is thought to act through antiinflammatory and antifibrotic pathways, although its exact mechanism is unknown. The FDA had declined to approve an initial marketing application for pirfenidone in a first review cycle in 2010. At that time, two 72week studies were submitted for review. Their primary efficacy variable was the absolute change in the percentage of the predicted FVC from baseline to week 72. In one study, pirfenidone had not been shown to have a significantly greater effect than placebo on that measure. At the time of the agency's decision not to approve pirfenidone, outside experts, including many members of the Pulmonary-Allergy Drugs Advisory Committee convened in May 2010, supported that decision. ${ }^{1,2}$

Before resubmitting its marketing application in 2014, the sponsor conducted a new 52-week study in which the primary efficacy end point - a decline in FVC from baseline to week 52 that was significantly smaller than that in the placebo group - was met. With two studies demonstrating a statistically significant effect on FVC and providing supportive evidence regard- 